\title{
Purification and Some Properties of an $\alpha$-D-Xylosidase from Bacillus sp. No. 693-1
}

\author{
Ning ZONG and Tsuneo YASUI \\ Institute of Applied Biochemistry, University of Tsukuba, \\ Tsukuba 305, Japan \\ Received August 9, 1988
}

\begin{abstract}
An $\alpha$-D-xylosidase from Bacillus sp. No. 693-1 was purified by precipitation with ammonium sulfate and successive chromatography on DEAE-Toyopearl 650 and hydroxyapatite. The purified enzyme, with its isoelectric point at $\mathrm{pH} 4.25$, had an apparent molecular weight of 82,000 in SDSpolyacrylamide gel electrophoresis, and 400,000 in gel filtration chromatography on Toyopearl $\mathrm{HW}$ 60. The optimum pH for enzyme action was 7.5 and the optimum temperature was $45^{\circ} \mathrm{C}$. The enzyme was stable from $\mathrm{pH} 6.0 \sim 8.5$ and up to $45^{\circ} \mathrm{C}$. The activity was inhibited by monoiodoacetic acid, $p$ $\mathrm{CNB}$, and metal ions such as $\mathrm{Zn}^{2+}, \mathrm{Cu}^{2+}$, and $\mathrm{Hg}^{2+}$. The $\alpha$-D-xylosidase was highly specific for $\alpha-$ xylosidic linkages, and hydrolyzed isoprimeverose [ $\alpha$-D-xylopyranosyl-(1 $\rightarrow 6)$-D-glucopyranose] to produce xylose and glucose, and hydrolyzed tamarind seed polysaccharide (soluble fraction) to release xylose as well.
\end{abstract}

In nature, there are various forms of polysaccharides in which xylose residues are connected with $\beta$-D-xylosidic linkages; xylan is typical. For this reason, $\beta$-D-xylanase [EC 3.2.1.8] and $\beta$-D-xylosidase [EC 3.2.1.37] which are able to hydrolyze $\beta$-D-xylosidic linkages, have been extensively studied. ${ }^{1 \sim 3)}$ In contrast, there are very few reported works on the occurrence of $\alpha$-D-xylosidic linkages. ${ }^{4 \sim 7)}$ However, in recent studies on the plant cell wall, the wide distribution of $\alpha$-xylosidic linkages has been confirmed in the cell wall polysaccharides called xyloglucan. ${ }^{8 \sim 19)}$ Moreover, it has been found that enzymatically modified xyloglucan derived from the cell wall is an important regulator in plant cell wall elongation. ${ }^{20,21)}$ Hence, it is unquestionable that the study of $\alpha$-xylosidase is very interesting and important. In our previous paper, ${ }^{15)}$ we reported the isolation of $\alpha$-D-xylosidase-producing microorganisms by a novel method, their taxonomic characterization, and the cultural conditions for enzyme production of Bacillus sp. No. 693-1. In this paper, the purification and some characteristics of $\alpha-\mathrm{D}-$ xylosidase from Bacillus sp. No. 693-1 are described.

\section{Materials and Methods}

Microorganism and preparation of crude enzyme. Bacillus sp. No. 693-1 was used for the production of enzyme. The bacterium was grown in a medium described in a previous paper ${ }^{25}$ in Erlenmeyer flasks at $30^{\circ} \mathrm{C}$ for 7 days on a shaker. Culture broth was centrifuged at $5000 \times g$ for $15 \mathrm{~min}$ to remove cells. The supernatant was used as an enzyme source.

Enzyme assay. $\alpha$-D-Xylosidase activity was measured by the amount of $p$-nitrophenol liberated from $p$-nitrophenyl $\alpha$-D-xylopyranoside $\left(\alpha-p\right.$-NPX) when incubated at $45^{\circ} \mathrm{C}$ for $10 \mathrm{~min}$ ( $\mathrm{pH} \mathrm{7.5)}$ as described in our previous paper. ${ }^{25}$ ) $\alpha$-D-Xylosidase activity is expressed as the amount of enzyme which releases $1 \mu \mathrm{mol}$ of $p$-nitrophenol per min under the above experimental conditions. The activities of other $\alpha$ - and $\beta$-glycosidases were measured and expressed as mentioned in our previous paper. ${ }^{25}$ )

Protein assay. Protein was measured by the method of Lowry et al. ${ }^{261}$ as modified by Hartree. ${ }^{27}$ Bovine serum albumin was used as a standard. In monitoring effluents of

Abbreviations: $\alpha$-MX $\mathrm{MX}_{1}$, methyl $\alpha$-D-Xylopyranoside; $\alpha$-IPX $\mathrm{I}_{1}$, isopropyl $\alpha$-D-xylopyranoside; $\alpha-p$-NPX, $p$ nitrophenyl $\alpha$-D-xylopyranoside; $p$-CMB, $p$-chloromercuribenzoic acid. 
column chromatography, protein was measured by the absorbance at $280 \mathrm{~nm}$.

General methods. Paper chromatography (PPC) was done on filter paper No. 51C (Toyoroshi Co., Ltd.) and also on the No. 527 (Toyoroshi Co., Ltd.) for the preparative PPC, with the solvent system of $n$-butanol-pyridinewater $(6: 4: 3, v / v)$ by the ascending method. Sugars were detected with $p$-anisidine hydrochloride. Thin-layer chromatography (TLC) was done on a Merck TLC plate of Silica Gel 60 with a solvent system of 1-propanol-water $(85: 15, \mathrm{v} / \mathrm{v})$. The sugars were detected by heating at $140^{\circ} \mathrm{C}$ for 3 min after spraying with $20 \%$ sulfuric acid in methanol. Enzyme solutions were concentrated by an ultrafiltration apparatus (Toyoroshi Co., Ltd.) using UK-10 membranes (Toyoroshi Co., Ltd.).

Preparation of isoprimeverose. Isoprimeverose [ $\alpha-\mathrm{D}-$ xylopyranosyl- $(1 \rightarrow \sigma)$-D-glucopyranose] was prepared by a modification of the method of Kato et al. $^{23}$ as follows: tamarind seed polysaccharide $(10 \mathrm{~g} / 1.01$ of water, $\mathrm{pH} 6.0)$, Kokulase $(3.0 \mathrm{~g}$, enzyme preparation from Aspergillus oryzae), Meicelase p-1 (2.0 g, from Trichoderma viride), and $\mathrm{NaN}_{3}(0.2 \mathrm{~g})$ were mixed and incubated at $40^{\circ} \mathrm{C}$ for $26 \mathrm{hr}$. After inactivation of the enzyme by heating, the reaction solution was concentrated to a small volume and then centrifuged to remove insoluble materials. The clear supernatant was fractionated by charcoal chromatography (on a column: $6 \times 45 \mathrm{~cm}$ ) and sugar fraction was further purified by preparative PPC. The prepared material was identified by methylation analysis.

Preparation of soluble fraction of tamarind seed polysaccharide. Five gram of dry tamarind seed powder was dissolved in $100 \mathrm{ml}$ of distilled water and stirred for $4 \mathrm{hr}$ at room temperature, and then centrifuged $(10,000 \times g$, $1.5 \mathrm{hr})$ to remove insoluble materials. The supernatant, the soluble fraction, was dialysed against distilled water using a Cellotube (1,000 cut) and concentrated to $100 \mathrm{ml}$. The concentration of prepared solution was measured by the phenol-sulfuric acid method ${ }^{28\}}$ with glucose as a standard.

Chemicals. The Kokulase was purchased from Sankyo Co., Ltd. Meicelase P-1 was purchased from Meiji Seika Kaisha, Ltd. Glucose C-Test was purchased from Wako Pure Chemical Industries, Ltd. Tamarind seed polysaccharide was purchased from Tokyo Kasei Industries, larchwood xylan from Sigma Co., Ltd., and all of the various $p$-nitrophenyl glycosides from Nakarai Chemicals Ltd. The xylooligosaccharides ${ }^{29)}$ (xylotriose to xylopentaose) and celloligosaccharides ${ }^{30)}$ (cellotriose and cellotetraose) were prepared in our laboratory. Standard monosaccharides and disaccharides were obtained from commercial sources. The trimethylsilylimidazole-C (TMSI-C) was from Gasukuro Kogyo Inc.

Purification of $\alpha-\mathrm{D}-x y$ losidase. All steps of purification were done at $4^{\circ} \mathrm{C}$ or $0^{\circ} \mathrm{C}$

Step 1. Ammonium sulfate precipitation. The supernatant of the cultural fluid was saturated to $65 \%$ with ammonium sulfate, and its $\mathrm{pH}$ was kept at 6.0 overnight; the proteinaceous precipitates were sedimented by centrifugation $(10,000 \times g, 30 \mathrm{~min})$. The precipitate was dissolved in a small amount of $0.02 \mathrm{M}$ phosphate buffer $\left(\mathrm{KH}_{2} \mathrm{PO}_{4}-\mathrm{Na}_{2} \mathrm{HPO}_{4}, \mathrm{pH} 7.0\right)$ and then desalted by dialysis against the same buffer using a Cellotube. The dialysed solution was centrifuged again to remove insoluble materials.

Step 2. DEAE-Toyopearl $650 \mathrm{M}$ ion-exchange chromatography (I). The dialyzed solution from step 1 was put on a column $(2.6 \times 45 \mathrm{~cm}$, bed volume $220 \mathrm{ml})$ of DEAEToyopearl $650 \mathrm{M}$ (Toyosoda Mfg. Co., Ltd.) ion exchanger pre-equilibrated with $0.02 \mathrm{M}$ phosphate buffer. The column was washed with the same buffer containing $0.15 \mathrm{~m}$ sodium chloride until the O.D. value of the effluent washing buffer was reduced to below 0.1 , and then a sodium chloride linear gradient was established by mixing $1000 \mathrm{ml}$ each of $0.15 \mathrm{M}$ and $0.5 \mathrm{M} \mathrm{NaCl}$ in the buffer. At an flow rate of $25 \mathrm{ml} / \mathrm{hr}, 8-\mathrm{ml}$ fractions were collected, and the protein content, and $\alpha$ - and $\beta$-D-xylosidase as well as $\alpha$ and $\beta$-D-glucosidase activities were measured. Fractions containing $\alpha$-D-xylosidase activity were pooled and concentrated by ultrafiltration using a UK-10 membrane.

Step 3. DEAE-Toyopearl $650 \mathrm{M}$ ion-exchange chromatography $(I I)$. The concentrate from step 2 was put on another column $(1.6 \times 45 \mathrm{~cm}$, bed volume $110 \mathrm{ml})$ of DEAE-Toyopearl $650 \mathrm{M}$ and chromatographed in the same way as mentioned in step 2 except for an elution rate. of $20 \mathrm{ml} / \mathrm{hr}$ and $5.0-\mathrm{ml}$ fractions.

Step 4. Hydroxyapatite chromatography. A column $(2.2 \times 45 \mathrm{~cm}$, bed volume $150 \mathrm{ml})$ packed with $\mathrm{Hy}-$ droxyapatite (Seikagaku Kogyo Inc.) was equilibrated with $0.007 \mathrm{M} \quad \mathrm{KH}_{2} \mathrm{PO}_{4}-\mathrm{K}_{2} \mathrm{HPO}_{4}$ buffer ( $\mathrm{pH}$ 6.8). The active fraction obtained from step 3 was put onto the hydroxyapatite column and washed with three times the column volume of starting buffer. Then, a $0.007 \sim 0.4 \mathrm{M}$ linear gradient of the same buffer was applied to elute the adsorbed proteins. Fractions of $3 \mathrm{ml}$ were collected at a rate of $15 \mathrm{ml} / \mathrm{hr}$ and analyzed for proteins and enzyme activities. Fractions showing only $\alpha$-D-xylosidase activity were pooled and desalted by ultrafiltration as described previously.

Electrophoresis: Polyacrylamide gel electrophoresis (Disc-PAGE) was done by the methods of Ornstein et $a l .^{31)}$ and Davis et $a l^{32)}$ The enzyme preparation was put on a $5.0 \%$ polyacrylamide gel at $\mathrm{pH} 8.3$. After electrophoresis at $4 \mathrm{~mA} /$ tube at $4 \%$, the protein band was stained with $0.25 \%$ of Coomassie Brilliant Blue R-250 solution (methanol-acetic acid-water $=5: 1: 5, \mathrm{v} / \mathrm{v}$ ) and destained by diffusion (methanol-acetic acid-water = $30: 10: 60, \mathrm{v} / \mathrm{v}$ ). Sodium dodecyl sulfate polyacrylamide gel electrophoresis (SDS-PAGE) of proteins was done on a $7.5 \%$ polyacrylamide gel by the method of Weber et al. ${ }^{33}$ 
The enzyme preparation was treated at $100^{\circ} \mathrm{C}$ for $3 \mathrm{~min}$ in $1 \%$ of SDS, $2 \% 2$-mercapto-ethanol, 10 mm sodium phos-

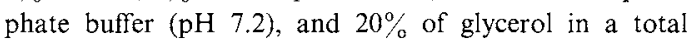
volume of $0.2 \mathrm{ml}$. A sample of the mixture was then placed on each gel. After electrophoresis at $6 \mathrm{~mA} /$ tube for $4 \mathrm{hr}$ at $20^{\circ} \mathrm{C}$, the bands of proteins were detected as described above. Ovalbumin $(45 \mathrm{~K})$, bovine serum albumin $(66 \mathrm{~K})$, phosphorylase $\mathrm{B}(92.5 \mathrm{~K}), \beta$-galactosidase $(116 \mathrm{~K})$, and myosin $(200 \mathrm{~K}$ ) (all from Bio-Rad Co., Ltd.) were used as molecular weight standards.

Isoelectric focusing. To investigate the homogeneity and isoelectric point of the $\alpha$-D-xylosidase, analytical isoelectric focusing was done in a column $(110 \mathrm{ml}$, Ampholine 8101 , LKB, Sweden). The $\mathrm{pH}$ and density gradient were formed by mixing sucrose $(0 \sim 40 \%)$ and ampholite solution ( $\mathrm{pH}$ $3 \sim 10$ or $2.5 \sim 5.0$ ). The voltage of $800 \mathrm{~V}$ run for $48 \mathrm{hr}$ at $4^{\circ} \mathrm{C}$. Two-ml fractions were collected, and their $\mathrm{pHs}$ were measured. Enzyme activity as well as absorption at $280 \mathrm{~nm}$ were measured after dialysis.

Gel filtration chromatography. A column $(1.9 \times 100 \mathrm{~cm}$, bed volume $270 \mathrm{ml}$ ) packed with Toyopearl HW-60 gel was used to measured the molecular weight of $\alpha$-Dxylosidase. The column was equilibrated with $0.02 \mathrm{M}$ $\mathrm{KH}_{2} \mathrm{PO}_{4}-\mathrm{Na}_{2} \mathrm{HPO}_{4}$ buffer containing $0.3 \mathrm{M}$ sodium chloride $(\mathrm{pH} 7.0)$. At an elution rate of $8 \mathrm{ml} / \mathrm{hr}, 1.5-\mathrm{ml}$ fractions were collected, and assayed for protein and $\alpha$-Dxylosidase activity. The column was calibrated with the following proteins of known molecular weights: $x$-chymotrypsinogen $\mathrm{A}(25 \mathrm{~K})$, egg albumin $(45 \mathrm{~K})$, bovine serum albumin $(68 \mathrm{~K})$, aldolase $(158 \mathrm{~K})$, katalase $(240 \mathrm{~K})$, ferritin $(450 \mathrm{~K})$, and thyroglobulin $(669 \mathrm{~K})$, all of which were purchased from Boehringer Mannheim Co., Ltd.

pH optimum and stability. To find the optimum $\mathrm{pH}$, the $\alpha$-D-xylosidase activity was measured under the standard assay conditions by using $0.1 \mathrm{M} \mathrm{KH}_{2} \mathrm{PO}_{4}-\mathrm{Na}_{2} \mathrm{HPO}_{4}$ buffer $(\mathrm{pH} \quad 5.0 \sim 8.0)$ as well as glycine-NaOH buffer $(\mathrm{pH}$ $8.0 \sim 9.0)$, instead of McIlvaine buffer ( $\mathrm{pH} 7.5$ ). To measure its $\mathrm{pH}$ stability, $0.01 \mathrm{~m}$ of $\mathrm{NaOAc}-\mathrm{HCl}$ buffer, $\mathrm{KH}_{2} \mathrm{PO}_{4}-\mathrm{Na}_{2} \mathrm{HPO}_{4}$ buffer, or glycine- $\mathrm{NaOH}$ buffer in the $\mathrm{pH}$ ranges of $2.5 \sim 5.0,5.0 \sim 8.0$, and $8.0 \sim 11.0$, respectively, were used. After the enzyme (0.009 units) was treated with each buffer for $15 \mathrm{~min}$ at $45^{\circ} \mathrm{C}$, remaining $\alpha$-Dxylosidase activity was assayed under the standard assay conditions.

Temperature optimum and stability. The $\alpha$-D-xylosidase activity was measured under standard conditions from $30 \sim 60^{\circ} \mathrm{C}$ to find the temperature optimum. After the enzyme was incubated at $\mathrm{pH} 7.5$ at various temperatures for $15 \mathrm{~min}$, and immediately cooled, its residual activity was measured under the standard assay conditions.

Effects of metal ions and inhibitors. The purified $\alpha-\mathrm{D}-$ xylosidase (0.009 units) was incubated for $15 \mathrm{~min}$ at $45^{\circ} \mathrm{C}$ in the presence of $2 \mathrm{~mm}$ of various metal ions and inhibitors except for $p$-chloromercuribenzoic acid ( $p$-CMB) with $0.2 \mathrm{~mm}$ concentration. The residual activity was measured under the standard assay conditions and the relative activity was expressed as a percentage of the enzyme activity in the absence of metal ions or inhibitors.

Apparent $\mathrm{Km}$ and $V_{\max }$ values. The Michaelis constants and the apparent $V_{\max }$ of purified enzyme for both $\alpha$ $p$-NPX and isoprimeverose were calculated by the Lineweaver-Burk reciprocal-plots. When $\alpha-p$-NPX was used as a substrate, the activity of $\alpha$-D-xylosidase was measured under the standard assay conditions with various final concentrations of $\alpha-p$-NPX from $0.2 \mathrm{~mm}$ to $10 \mathrm{~mm}$, but in the case of isoprimeverose, the substrate concentration was varied from $10 \mathrm{~mm}$ to $100 \mathrm{~mm}$, and the enzyme activity was measured by the glucose oxidase method to find the amount of glucose released from isoprimeverose.

Substrate specificity. The reaction mixture, containing $0.5 \mathrm{ml}$ of $5 \mathrm{~mm}$ glycoside, $0.5 \mathrm{ml}$ of Mcllvaine buffer ( $\mathrm{pH}$ 7.5 ), and $0.5 \mathrm{ml}$ of purified enzyme solution (0.045 units) was incubated and the activities were measured under the standard assay conditions. In the case of poly or oligosaccharide, $2 \%$ larchwood xylan, $1.0 \%$ tamarind seed polysaccharide (soluble), or $0.7 \%$ or $5.0 \%$ of isoprimeverose, were incubated with the enzyme $(0.045 \sim 1.0$ units $)$ and 2 drops of toluene under the standard conditions. At intervals, samples of the reaction mixture were taken out, inactivated by heating, concentrated, and then chromatographed to $\mathrm{PPC}$ or TLC.

Anomer analysis. The identification of anomeric forms of xylose initially released from $\alpha-p-N P X$ by the $\alpha$-Dxylosidase was done by gas-liquid chromatography (GLC) by the trimethylsilylimidazole-C (TMSI-C) method. The enzyme reaction was done as follows: two hundred $\mu \mathrm{l}$ of $\alpha$ $p$-NPX $(20 \mathrm{mM}$, in $0.02 \mathrm{M}$ Mcllvaine buffer, $\mathrm{pH} 7.5)$ and $200 \mu \mathrm{l}$ of enzyme solution ( 0.08 units) were mixed. After being incubated at $45^{\circ} \mathrm{C}$ for $2 \mathrm{~min}$, a sample of the reaction mixture was promptly taken out, cooled in a cold ethanol bath $\left(-45^{\circ} \mathrm{C}\right)$, and freeze-dried. Then TMSI-C $(200 \mu 1)$ was added to the dry sample. The mixture was incubated at $60^{\circ} \mathrm{C}$ for $15 \mathrm{~min}$ to complete silylation. A control experiment $(0 \mathrm{~min})$ was done by directly adding TMSI-C a crystal $D$-xylose sample for silylation. The ratio of $\alpha$ - and $\beta$-D-xylose in water solution at equilibrium was also measured. Twenty $\mathrm{mm}$ xylose solution (in $0.02 \mathrm{M}$ McIlvaine buffer, $\mathrm{pH} 7.5$ ) was incubated at $45^{\circ} \mathrm{C}$ for $2.5 \mathrm{hr}$. After freeze-drying, silylation was done as described above. For measuring the silylatants, a Shimadzu Gas Chromatography Model GC-7A as well as a column packed with $5 \%$ OV-17 $(3 \mathrm{~mm} \times 2 \mathrm{~m})$ were used in analysis: $8 \mathrm{~min}$ isothermal hold at $165^{\circ} \mathrm{C}$ followed by $1{ }^{\circ} \mathrm{C} / \mathrm{min}$ increase to $200^{\circ} \mathrm{C}$. Peak areas were measured with a Chromatopac C-EIB (Shimadzu). 


\section{Results and Discussion}

\section{Purification of $\alpha-\mathrm{D}-x y$ losidase}

The purification of $\alpha$-D-xylosidase are summarized in Table $\mathrm{I}$.

First, a supernatant of cultural fluid was precipitated with $\left(\mathrm{NH}_{4}\right)_{2} \mathrm{SO}_{4}(65 \%$ saturation). After dialysis and concentration, the recovery of $\alpha$-D-xylosidase activity in this step was $86 \%$ and a sixfold purification was achieved. The $\alpha$ D-xylosidase fraction from step 1 was then chromatographed on an ion exchange column of Toyopearl $650 \mathrm{M}$. $\alpha$-D-Xylosidase as well as other contaminating enzymes such as $\beta$-Dxylosidase and $\beta$-D-glucosidase were adsorbed to the ion exchanger. As shown in Fig. 1, $\alpha-\mathrm{D}$ xylosidase activity peak appeared at the $0.23 \mathrm{M}$ $\mathrm{NaCl}$ eluate with a shoulder peak, but $\beta$ D-xylosidase and $\beta$-D-glucosidase activities were observed in the eluate of about 0.17 and $0.20 \mathrm{M} \mathrm{NaCl}$. Thus, these enzymes were effectively separated and the $\alpha$-D-xylosidase fraction was also separated from pigments at this step.

To separate these enzymes completely, they were chromatographed on Toyopearl $650 \mathrm{M}$ again, and a similar elution pattern was obtained. Though the fractions containing $\alpha-D-$ xylosidase activity did not show any $\beta$-Dxylosidase or $\beta$-D-glucosidase activities, the $\alpha$ $D$-xylosidase fraction was heterogeneous on disc-PAGE.

The final purification step involved hydroxyapatite chromatography (Fig. 2). At this step, in spite of the fact that the specific activity of $\alpha$-D-xylosidase did not increase contrary to expectation, the $\alpha-\mathrm{D}-\mathrm{xyl}$ losidase preparation gave a single and sharp protein band on disc-PAGE (FIg. 3, A), indicating homogeneity.

Our methods for isolation and purification have allowed us to obtain a homogeneous $\alpha$ xylosidase from Bacillus sp. No. 693-1. The purified $\alpha$-D-xylosidase had an overall activity yield of $26 \%$ and a 23 -fold increase in specific activity (Table I).

Homogeneity and molecular weight of purified $\alpha$-D-xylosidase

Upon disc-PAGE ( $5 \%$ gel), the purified $\alpha$-D-

Table I. Summary of Purification of $\alpha$-D-Xylosidase from Bacillus sp. No. 693-1

\begin{tabular}{|c|c|c|c|c|c|c|c|c|}
\hline & $\begin{array}{c}\text { Purification } \\
\text { step }\end{array}$ & $\begin{array}{c}\text { Total } \\
\text { protein } \\
(\mathrm{mg})\end{array}$ & $\begin{array}{l}\text { Total } \\
\alpha \text {-xylo- } \\
\text { sidase } \\
\text { activity } \\
\text { (U) }\end{array}$ & $\begin{array}{c}\text { Specific } \\
\alpha \text {-xylo- } \\
\text { sidase } \\
\text { activity } \\
(\mathrm{U} / \mathrm{mg})\end{array}$ & $\begin{array}{c}\alpha \text {-Xylo- } \\
\text { sidase } \\
\text { activity } \\
\text { yield } \\
(\%)\end{array}$ & $\begin{array}{l}\beta \text {-Xylo- } \\
\text { sidase } \\
\text { activity }\end{array}$ & $\begin{array}{l}\beta \text {-Gluco- } \\
\text { sidase } \\
\text { activity }\end{array}$ & $\begin{array}{l}\text { Homo- } \\
\text { geneity }\end{array}$ \\
\hline & $\begin{array}{l}\text { Culture } \\
\text { supernatant }\end{array}$ & 24,000 & 232.5 & 0.01 & 100 & $+t$ & ++ & no \\
\hline 1. & $\begin{array}{l}\left(\mathrm{NH}_{4}\right)_{2} \mathrm{SO}_{4} \\
\text { precipitation } \\
(65 \% \text {-satd. })\end{array}$ & 3,056 & 200.5 & 0.065 & 86 & ++ & ++ & no \\
\hline 2. & $\begin{array}{l}\text { DEAE-Toyopearl } \\
650 \mathrm{M} \text { column } \\
\text { chromatography } \\
\text { (I) }\end{array}$ & 688 & 175.5 & 0.25 & 76 & + & + & no \\
\hline 3. & $\begin{array}{l}\text { DEAE-Toyopearl } \\
650 \mathrm{M} \text { column } \\
\text { chromatography } \\
\text { (II) }\end{array}$ & 374 & 105.5 & 0.28 & 45 & - & - & no \\
\hline 4. & $\begin{array}{l}\text { Hydroxyapatite } \\
\text { column } \\
\text { chromatography }\end{array}$ & 265 & 61.2 & 0.23 & 26.3 & - & - & yes \\
\hline
\end{tabular}




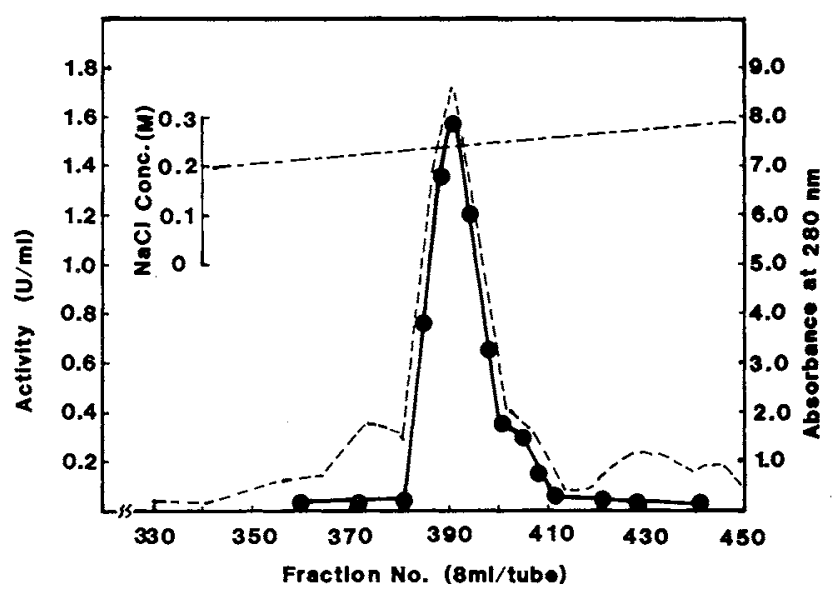

Fig. 1. The First Ion Exchange Chromatogram on a DEAE-Toyopearl $650 \mathrm{M}$ Column of $\alpha$-D-Xylosidase from Bacillus sp. No. 693-1.

The $\alpha$-D-xylosidase fraction from the $\left(\mathrm{NH}_{4}\right)_{2} \mathrm{SO}_{4}$ precipitation was put on a column of DEAE-Toyopear1 $650 \mathrm{M}(2.6 \times 45 \mathrm{~cm})$ equilibrated with $0.02 \mathrm{M} \mathrm{KH}_{2} \mathrm{PO}_{4}-\mathrm{Na}_{2} \mathrm{HPO}_{4}$ buffer $(\mathrm{pH} 7.0)$, and then eluted by a sodium chloride linear gradient $(0.15 \sim 0.5 \mathrm{M})$. The size of each fraction was $8 \mathrm{ml}$ and the flow rate of eluent was $25 \mathrm{ml}$ per hour.

Symbols: - - enzyme activity; ----, protein; -.-, molar concentration of $\mathrm{NaCl}$.

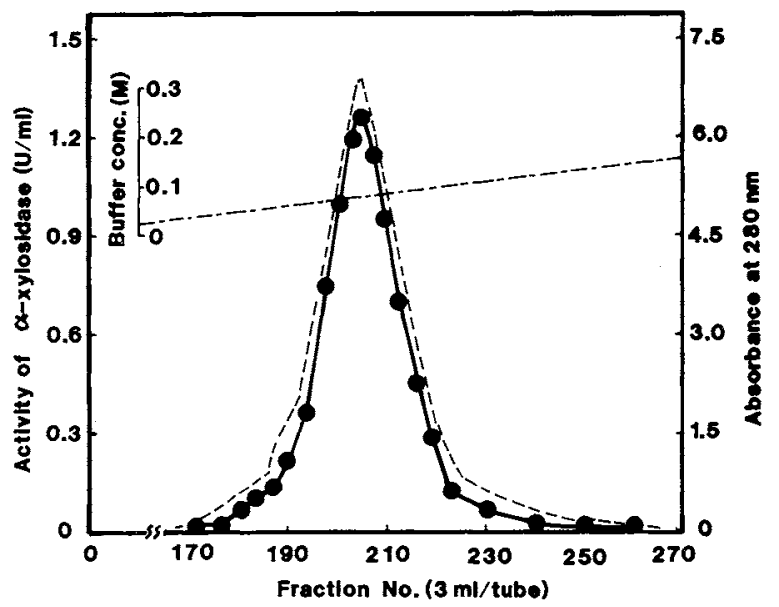

Fig. 2. Chromatogram on a Hydroxyapatite Column of $\alpha-\mathrm{D}-\mathrm{X}$ ylosidase from Bacillus sp. No. 693-1.

The $\alpha$-D-xylosidase fractions from the second DEAE-Toyopearl $650 \mathrm{M}$ chromatography were adsorbed on a hydroxyapatite column $(2.2 \times 45 \mathrm{~cm})$ equilibrated with $0.007 \mathrm{M} \mathrm{KH}_{2} \mathrm{PO}_{4}-\mathrm{K}_{2} \mathrm{HPO}_{4}$ buffer $(\mathrm{pH} 6.8)$, and then eluted by a $0.007 \sim 0.4 \mathrm{~m}$ linear gradient of the same buffer. Fractions of $3 \mathrm{ml}$ were collected at a flow rate of $15 \mathrm{ml}$ per hour. The symbols are the same as in Fig. 1.

xylosidase gave a single, sharp protein band (Fig. 3, A), and SDS-PAGE (7.5\% gel) also proved the homogeneity of the enzyme (Fig. 3, B).

The molecular weight of the purified enzyme was $40 \times 10^{4}$ by gel filtration. The molecular weight of the subunit was also about $8.2 \times 10^{4}$ by SDS-PAGE. It was supposed that the enzyme was of an oligomeric structure. On the other hand, the enzyme may be a component bound to the cell wall or cell membrane and released into the culture broth with the au- 


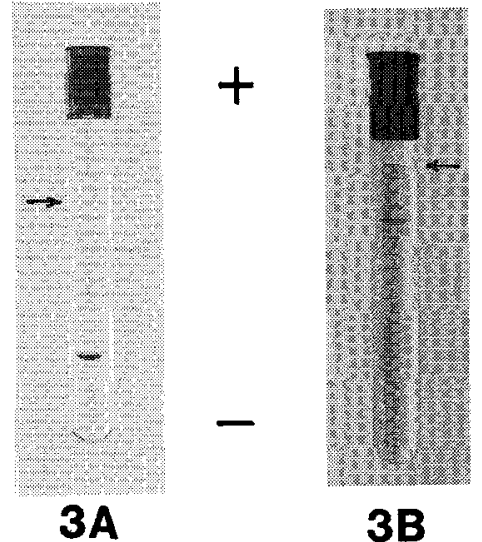

Fig. 3. Polyacrylamide Gel Electrophoresis of the Purified $\alpha-\mathrm{D}-X y$ losidase from Bacillus sp. No. 693-1.

Gel 3A: Electrophoresis of the native enzyme, on a $5 \%$ gel column, run at $\mathrm{pH} 8.3$ and $4 \mathrm{~mA}$ per column.

Gel 3B: Electrophoresis in the presence of SDS. The purified enzyme treated with SDS at $100^{\circ} \mathrm{C}$ for 3 min was applied on a $7.5 \%$ gel containing $0.1 \%$ SDS and run at $6 \mathrm{~mA}$ per column.

Arrows indicate the top of resolving gel.

tolysis of the cells, because the $\alpha$-D-xylosidase activity in the culture broth increased with decrease of cell weight. ${ }^{25)}$ Similarly, $\alpha$-Dxylosidades I and II, from $A$. niger, had high molecular weights as well, $49 \times 10^{4}$ for the $\alpha$ xylosidase I and $80 \times 10^{4}$ for the $\alpha$-xylosidase II, which it was suggested were released with the autolysis of mycelia. ${ }^{22,23)}$

\section{Isoelectric point}

First, isoelectric focusing was done using carrier Ampholine ( $\mathrm{pH} 3 \sim 10)$ and second, it was was repeated by using Ampholine with a narrow $\mathrm{pH}$ range $(2.5 \sim 5.0)$. Both tests gave the same isoelectric point $(\mathrm{pH} \mathrm{4.25)}$ as shown in Fig. 4. The homogeneity of the enzyme was also confirmed by isoelectric focusing giving a single, sharp peak.

Effects of $p H$ and temperature on activity and stability

The $\mathrm{pH}$ optimum and $\mathrm{pH}$ stability of $\alpha-\mathrm{D}$ xylosidase activity were investigated by measuring the enzyme activity toward $\alpha-p-\mathrm{NPX}$ from $\mathrm{pH} 5.0 \sim 9.0$ or $\mathrm{pH} 2.5 \sim 11.0$. The maxi-

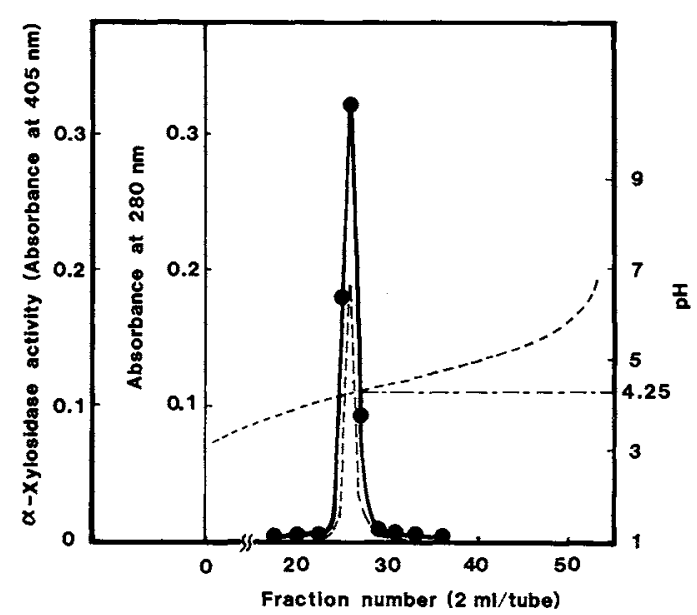

Fig. 4. Isoelectric Focusing of the Purified $\alpha$-DXylosidase from Bacillus sp. No. 693-1.

Isoelectric focusing was done in a $110-\mathrm{ml}$ column (LKB) at $4^{\circ} \mathrm{C}$. Carrier Ampholine ( $\mathrm{pH} 2.5 \sim 5.0$ ) was used in a sucrose density gradient. A voltage of $800 \mathrm{~V}$ was applied for $48 \mathrm{hr}$. The volume of each fraction collected was $2 \mathrm{ml}$. Symbols: - - enzyme activity; -- -- , absorbance at $280 \mathrm{~nm}$; -----, pH.

mal activity of the enzyme was observed at pH 7.5. $\alpha$-D-Xylosidase preserved its activity at $\mathrm{pH} 5.0 \sim 9.0$, at $45^{\circ} \mathrm{C}$ for $15 \mathrm{~min}$.

The temperature dependence of $\alpha-\mathrm{D}-\mathrm{xy}$ losidase activity was also studied by measuring the enzyme activity toward $\alpha-p-\mathrm{NPX}$ at $30 \sim 60^{\circ} \mathrm{C}$. The enzyme hydrolyzed $\alpha-p$-NPX with the highest rate at $45^{\circ} \mathrm{C}$ and retained almost all activity at temperatures up to $45^{\circ} \mathrm{C}$, $50 \%$ activity at $50^{\circ} \mathrm{C}$, and lost its activity at $55^{\circ} \mathrm{C}$ completely.

In comparison with the purified $\alpha$-D-xylosidase I and II from $A$. niger (AMS 4111), 22 24) the bacterial $\alpha$-D-xylosidase had a higher alkaline $\mathrm{pH}$ optimum, $\mathrm{pH} 7.5$, vs $\mathrm{pH} 2.5 \sim 3.0$. The temperature optima of bacterial and fungal enzymes were both at $45^{\circ} \mathrm{C}$, but there was a difference between their thermostabilities. Bacterial enzyme had a much lower thermostability (up to $45^{\circ} \mathrm{C}$ ) than that of fungal enzyme (up to $60^{\circ} \mathrm{C}$ ).

\section{Effects of metal ions and chemicals}

Table II shows the effects of various metal ions and chemicals on the enzyme activity. 
Table II. Effects of Various Chemicals on the ACTIVITY OF $\alpha$-D-XYLOSIDASE From Bacillus sp. No. 693-1

The reaction mixture $(400 \mu 1)$, containing $2 \mathrm{mM}$ of reagents, 0.009 units enzyme, $0.01 \mathrm{M} \mathrm{KH}_{2} \mathrm{PO}_{4}-\mathrm{Na}_{2} \mathrm{HPO}_{4}$ buffer ( $\mathrm{pH} 7.5$ ) was incubated at $45^{\circ} \mathrm{C}$ for $15 \mathrm{~min}$, and then $0.5 \mathrm{ml}$ of $5 \mathrm{~mm} p$-nitrophenyl $\alpha$-D-xyloside and $600 \mu \mathrm{l}$ of McIlvaine buffer ( $\mathrm{pH} 7.5$ ) were added. The residual activities were measured as described in the text and were expressed in terms of percentage of the control (no reagent).

\begin{tabular}{|c|c|c|c|}
\hline \multirow[b]{2}{*}{ Chemicals } & \multirow{2}{*}{$\begin{array}{l}\text { Concn. } \\
\left(\times 10^{-3} \mathrm{M}\right)\end{array}$} & \multicolumn{2}{|c|}{ Relative activity $(\%)$} \\
\hline & & No. 693-1 & $\begin{array}{c}\text { Asp. niger } \\
(\mathrm{I})^{24\}}\end{array}$ \\
\hline None & 2.0 & 100 & 100 \\
\hline $\mathrm{CaCl}_{2}$ & 2.0 & 104 & 111 \\
\hline $\mathrm{MgCl}_{2}$ & 2.0 & 106 & 108 \\
\hline $\mathrm{MnCl}_{2}$ & 2.0 & 117 & 106 \\
\hline $\mathrm{FeCl}_{3}$ & 2.0 & 108 & 87 \\
\hline $\mathrm{AlCl}_{3}$ & 2.0 & 96 & - \\
\hline $\mathrm{ZnCl}_{2}$ & 2.0 & 17 & 100 \\
\hline $\mathrm{CuCl}_{2}$ & 2.0 & 17 & 80 \\
\hline $\mathrm{HgCl}_{2}$ & 2.0 & 17 & 74 \\
\hline$p$-CMB & 0.2 & 16 & 100 \\
\hline Iodoacetic acid & 2.0 & 19 & 100 \\
\hline SDS & 2.0 & 63 & 26 \\
\hline EDTA & 2.0 & 102 & 93 \\
\hline Glucono- $\delta$-lactone & 2.0 & 100 & - \\
\hline 2-Mercaptoethanol & 2.0 & 92 & 104 \\
\hline
\end{tabular}

None of the chemicals tested significantly enhanced the activity of the enzyme except that $\mathrm{Mn}^{2+}$ ions had a slight activating effect $(\sim 17 \%)$. The $\alpha$-D-xylosidase was markedly inhibited by metal ions of $2 \mathrm{~mm} \mathrm{Zn}^{2+}, \mathrm{Cu}^{2+}$, and $\mathrm{Hg}^{2+}(83 \%$ each inhibition), but EDTA did not inhibit. Besides, it was noticed that the enzyme activity was inhibited $84 \%$ by $0.2 \mathrm{~mm}$ $p$-CMB and $81 \%$ by $2 \mathrm{~mm}$ iodoacetic acid, suggesting the participation of sulfhydryl groups in the active site. The bacterial enzyme was inhibited by chemicals more easily than the fungal enzymes were. ${ }^{22,24)}$

\section{Kinetic properties}

Evaluated from Lineweaver-Burk plots, the Michaelis constant, $\mathrm{Km}$, and relative maximum velocity, $V_{\max }$, were $1.0 \mathrm{~mm}$ and 0.15 $\mu \mathrm{mol} / \mathrm{min} / \mathrm{mg}$ protein for $\alpha-p-\mathrm{NPX}$, and 55.6 $\mathrm{mm}$ and $2.22 \mu \mathrm{mol} / \mathrm{min} / \mathrm{mg}$ protein for isoprime-

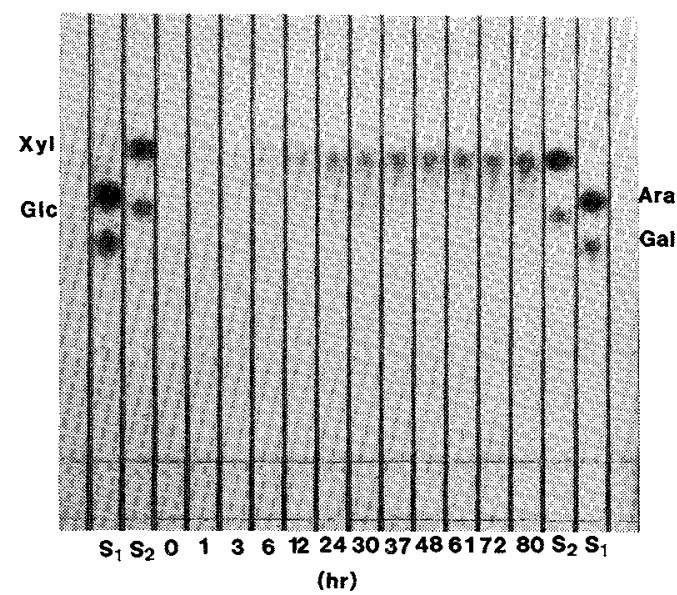

Fig. 5. Thin-layer Chromatogram of $\alpha$-D-Xylosidase Action Products on Tamarind Seed Polysaccharide (Soluble Fraction).

The reaction mixture, containing $50 \mathrm{mg}$ of tamarind seed polysaccharide and 1.0 units of the purified $\alpha-\mathrm{D}$-xylosidase in $5 \mathrm{ml}$ of McIlvaine buffer with $0.02 \% \mathrm{NaN}_{3}(\mathrm{pH} \mathrm{7.5,10}$ times of dilution), was incubated at $45^{\circ} \mathrm{C}$. A sample of the reaction mixture was taken out at intervals as indicated in the figure, boiled to stop the enzyme action, and chromatographed on a TLC plate of Silica Gel 60 with a solvent system of 1-propanol-water $(85: 15, \mathrm{v} / \mathrm{v})$.

$\mathrm{S}_{1}$, arabinose and galactose; $\mathrm{S}_{2}$, xylose and glucose; Xyl, xylose; Ara, arabinose; Glc, glucose; Gal, galactose.

verose. Contrary to results of the fungal $\alpha$ D-Xylosidase, ${ }^{22,24)}$ the $K m$ value for $\alpha-p$-NPX of the enzyme was far lower than that for isoprimeverose. This fact indicates that the bacterial enzyme has a much higher affinity for $\alpha-p$-NPX than that for isoprimeverose.

\section{Substrate specificity}

The substrate specificity of $\alpha$-xylosidase was examined by testing its ability to hydrolyze the following ten glycosides: $p$-nitrophenyl $\alpha-\mathrm{D}$ xyloside, $\beta$-D-xyloside, $\alpha$-D-glucoside, $\beta$-Dglucoside, $\alpha$-D-galactoside, $\beta$-D-galactoside, $\alpha$ D-mannoside, $\beta$-D-mannoside, $\alpha$-L-fucoside, and $\beta$-L-fucoside ( $5 \mathrm{~mm}$ each). Among them, only the $p$-nitrophenyl $\alpha$-D-xyloside was hydrolyzed and the other glycosides were not found to be substrates under such experimental conditions.

Some polysaccharides such as larchwood xylan, tamarind seed polysaccharide (soluble 


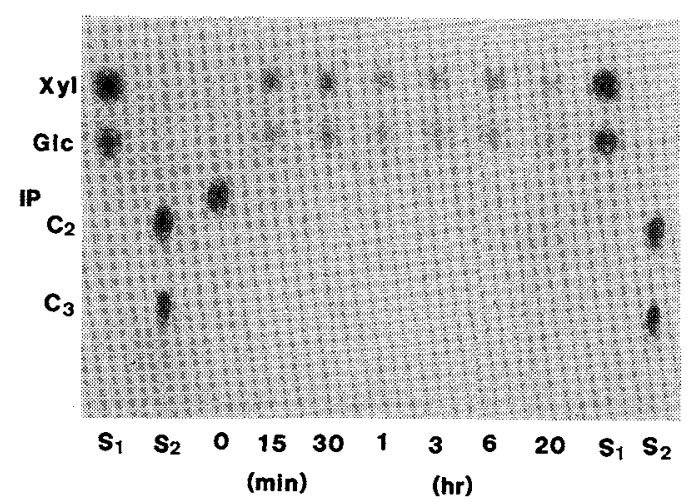

Fig. 6. Paper Chromatogram of the $\alpha-D-X y l o s i d a s e$ Action Products on Isoprimeverose $(0.7 \%)$.

The reaction mixture, containing $0.7 \%$ of isoprimeverose, $0.08 \mathrm{U}$ of purified enzyme, McIlvaine buffer ( $\mathrm{pH} 7.5,50$ times of elution) and two drops toluene in the total volume of $600 \mu$, was incubated at $45^{\circ} \mathrm{C}$. A sample of the reaction mixture was taken at the times indicated in the figure; the PPC solvent system was $n$-butanol-pyridine-water $(6: 4: 3, v / v)$.

$\mathrm{S}_{1}$, xylose and glucose; $\mathrm{S}_{2}$, cellobiose and cellotriose; $\mathrm{Xyl}$, xylose; Glc, glucose; IP, isoprimeverose; $\mathrm{C}_{2}$, cellobiose; $\mathrm{C}_{3}$, cellotriose.

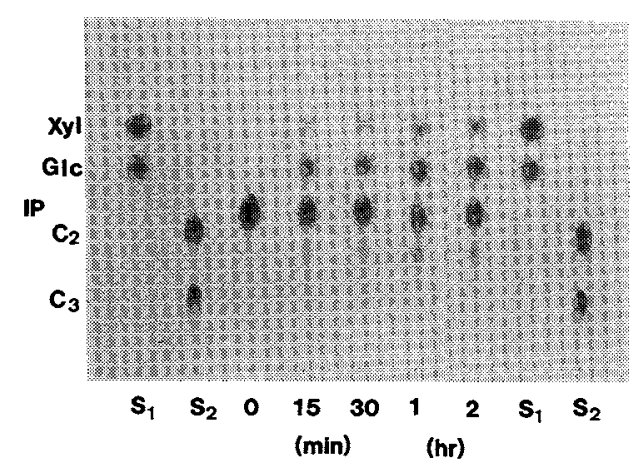

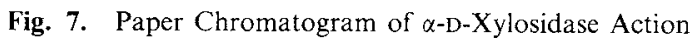
Products on Isoprimeverose $(5 \%)$.

The method and symbols are the same as in Fig. 6.

fraction), and a disaccharide, isoprimeverose, were tested as substrates as well. The $\alpha$-Dxylosidase was not able to hydrolyze xylan at all, but did hydrolyze tamarind seed polysaccharide (soluble fraction) to release xylose (Fig. 5). As shown in Fig. 6, the enzyme hydrolyzed the isoprimeverose to produce $x y-$ lose and glucose at $0.7 \%$ concentration of substrate. However, similar to most glycosidases, it showed transfer activity to form some oligosaccharides at a higher concentration $(5 \%)$ of isoprimeverose (Fig. 7).

These results and findings indicated that we could use the purified $\alpha$-D-xylosidase preparation as an efficient specific tool for elucidating the structures of saccharides containing $\alpha$ xylosidic linkages. Further studies on the substrate specificity of the enzyme will be published elsewhere.

\section{Anomeric configuration of the reaction product D-xylose}

The anomeric configuration of D-xylose released from $\alpha-p$-NPX by the $\alpha$-D-xylosidase was identified by GLC. The ratio of $\alpha$ - and $\beta$ D-xylose in equilibrium was $37.7 \%: 62.3 \%$, which was very close to the reported value $(37 \%: 63 \%){ }^{34)}$ But it was found that the ratio of $\alpha$ - and $\beta$-D-xylose in the reaction mixture after 2 min of reaction was $75 \%: 25 \%$, indicating that there was the retention of configuration in $D$-xylose formed by the $\alpha$-D-xylosidase. Glycanases and glycosidases acting with retention of configuration are regarded as enzymes probably operated by a single-step mechanism. ${ }^{35)}$ There was some information on the anomeric configuration in the released $D^{-}$ xylose for $\beta-\mathrm{D}-\mathrm{xy}$ losidase ${ }^{35 \sim 40)}$ However, for $\alpha$-D-xylosidase, the information on the anomeric configuration of released $\mathrm{D}$-xylose is reported for the first time in this paper.

\section{References}

1) K. Poutanen, M. Ratto, J. Puls and L. Viikari, $J$. Biotechnol., 6, 49 (1987).

2) P. Biely, Trends in Biotechnology, 3, 286 (1985).

3) R. E. H. Dekker and G. N. Richards, "Advances in Carbohydrate Chemistry and Biochemistry," Vol. 32, ed. by R. S. Tipson and D. Horton, Academic Press Inc., New York, 1976, p. 277.

4) H. C. Srivastava and P. P. Singh, Carbohydr. Res., 4, 326 (1967).

5) I. R. Siddiqui and P. J. Wood, Carbohydr. Res., 17, 97 (1971).

6) D. S. Hsu and R. E. Reeves, Carbohydr. Res., 5, 202 (1967).

7) G. O. Aspinall, "Advances in Carbohydrate Chemistry and Biochemistry," Vol. 24, ed. by L. W. 
Melville et al., Academic Press Inc., New York, 1969, p. 333.

8) W. D. Bauer, K. W. Talmadge, K. Keegstra and P. Albersheim, Plant Physiol., 51, 174 (1973).

9) B. M. Wilder and P. Albersheim, Plant Physiol., 51, 889 (1973).

10) Y. Kato and K. Matsuda, Plant Cell Physiol., 17, 1185 (1976).

11) Y. Kato, N. Asano and K. Matsuda, Plant Cell Physiol., 18, 821 (1977).

12) T. Hayashi, Y. Kato and K. Matsuda, Plant Cell Physiol., 21, 1405 (1980).

13) Y. Kato and K. Matsuda, Plant Cell Physiol., 18, 1089 (1977)

14) T. Watanabe, K. Takahashi and K. Matsuda, Agric. Biol. Chem., 44, 791 (1980).

15) N. Shibuya and A. Misaki, Agric. Biol. Chem., 42, 2267 (1978).

16) Y. Kato, K. Iki and K. Matsuda, Agric. Biol. Chem., 45, 2745 (1981).

17) Y. Kato, S. Ito, K. Iki and K. Matsuda, Plant Cell Physiol., 23, 351 (1982).

18) Y. Kato, R. Shiozawa, S. Takeda, S. Ito and K. Matsuda, Carbohydr. Res., 109, 233 (1982).

19) J. Thomas, A. G. Darvill, P. Albersheim, Plant Physiol., 72, s-59 (1983).

20) W. S. York, A. G. Darvill and P. Albersheim, Plant Physiol., 75, 295 (1984).

21) M. E. Terry and R. L. Jones, Plant Physiol., 68, 531 (1981).

22) J. Matsushita, Y. Kato and K. Matsuda, Agric. Biol. Chem., 51, 2015 (1987).

23) Y. Kato, J. Matsushita and K. Matsuda, J. Ferment. Technol., 63, 389 (1985).
24) J. Matsushita, Y. Kato and K. Matsuda, J. Biochem., 98, 825 (1985).

25) N. Zong, K. Nakanishi, T. Yasui and K. Yamasato, submitted for press.

26) O. H. Lowry, N. J. Rosebrough, A. L. Farr and R. J. Raudall, J. Biol. Chem., 193, 265 (1951).

27) E. F. Harfree, Anal. Biochem., 48, 422 (1972).

28) M. Dubois, K. A. Gilles, J. K. Hamilton, P. A. Rebers and F. Smith, Anal. Chem., 193, 256 (1951).

29) I. Kusakabe, T. Yasui and T. Kobayashi, Nippon Nōgeikagaku Kaishi, 49, 383 (1975).

30) G. L. Miller, "Methods in Carbohydrate Chemistry," Vol. III, ed. by R. L. Whistler et al., Academic Press Inc., New York, 1963, p. 134.

31) L.Ornstein, Ann. N.Y. Acad. Sci., 121, 321 (1964).

32) B. J. Davis, Ann. N.Y. Acad. Sci., 121, 404 (1964).

33) K. Weber and M. Osborn, J. Biol. Chem., 244, 4406 (1969).

34) W. Pigman, H. S. Isbell, "Advances in Carbohydrate Chemistry," Vol. 23, ed. by M. L. Wolfrom and R. S. Tipson, Academic Press Inc., New York, 1968, p. 11.

35) F. Deleyn, M. Claeyssens, J. V. Beeumen and C. K. D. Bruyne, Can. J. Biochem., 56, 43 (1978).

36) M. Matsuo, A. Fujie, Maung $W$ in and T. Yasui, Agric. Biol. Chem., 51, 2367 (1987).

37) M. Matsuo and T. Yasui, Agric. Biol. Chem., 45, 1603 (1981).

38) H. K. Hilderson, F. V. Doorslaer and C. K. De Bruyne, Carbohydr. Res., 65, 219 (1978).

39) M. Matsuo and T. Yasui, Agric. Biol. Chem., 48, 1845 (1984).

40) M. Matsuo and T. Yasui, Agric. Biol. Chem., 48, 1853 (1984). 